\title{
Rafflesia patma Blume in Pananjung Pangandaran Nature Reserve, West Java: Population Structure, Distribution Patterns, and Environmental Influences
}

\author{
Bahana Aditya Adnan'1, Suwarno Hadisusanto', Purnomo'* \\ 1)Faculty of Biology, Universitas Gadjah Mada, Jl. Teknika Selatan, Sekip Utara, Yogyakarta 55281, Daerah Istimewa Yogyakarta, \\ Indonesia \\ * Corresponding author, email: purnomods@ugm.ac.id
}

\begin{abstract}
Rafflesia patma is an endemic plant of Pangandaran, West Java which is protected because of its rare status. The purpose of this research is to study the population structure, distribution patterns, and the effect of the physical environment of abundance R. patma in Pananjung Pangandaran Nature Reserve, West Java. The method used in this research was a survey method with a purposive sampling technique. Sampling was conducted using quadrat plots. The population pattern distribution was defined by a standardized Morisita index, and the analysis of abiotic environmental factors was determined by Principal Component Analysis (PCA) using PAST3. The results showed that there were 114 R. patma individuals scattered in several research areas in Pananjung Pangandaran Nature Reserve, they were Gua Parat (3 individuals), Cilegon (13 individuals), Pasir Putih (12 individuals), Badeto (48 individuals), and Curug Leutik (38 individuals). The distribution pattern of R. patma in Pananjung Pangandaran Nature Reserve was clustered with the Morisita index value (Id) $>1$. Based on the PCA analysis, results that support the classification of the cluster analysis were obtained. Based on four abiotic environmental conditions analyzed, the most dominant character in influencing the distribution patterns and population structure of R. patma is light intensity.
\end{abstract}

Keywords: distribution pattern, habitat, nature reserve, population structure, R. patma Blume

\section{INTRODUCTION}

Rafflesia patma is a unique plant that lives in the tropical rainforest ecosystem of Malesiana. The plants do not have any stem, leaves, roots, or photosynthetic organs (Wicaksono et al. 2016). R. patma is a parasitic plant on the tree as the host in its habitat. The nutritional needs in its life cycle are taken from the host plant. The intake of nutrients from the host plant is carried out using suction roots to absorb photosynthate into the body organs of R. patma. The characteristic of Rafflesia is a rare plant species must receive a priority for conservation because the population in nature is small (rare) and is an endemic species. Scarcity of this species is caused by Rafflesia having different biological characteristics from other plants, namely having an annual life cycle, being a parasite in certain liana species, and breeding 
difficult. This leads to the notion that Rafflesia chose certain environmental conditions to support its breeding and growth (Hidayati \& Walck 2016; Priatna et al. 1989).

The population of Rafflesia in nature is very small. The small number coupled with the sporadic and inconsistent flowering seasons causes the scarcity of male and female flowers to bloom at the same time. In the case of R. Patma, in Pangandaran (West Java) the population is dominated by male flowers (Hidayati et al. 2000), which means that the chances of pollination between male and female flowers are reduced. This opportunity is further reduced by the short bloom period, around 4-5 days. Consequently, the pollen viability of male flowers will be very limited. Nais (2001) stated that the viability of $R$. keithii pollen was only 72 hours after being separated from the flower. This means that during this time the pollinating insects must find the female flowers in bloom and pollinate them. It is not yet known how long the viability of $R$. patma pollen is.

Rafflesia has specific life characteristics so that it requires suitable habitat to support its growth, distribution, and sustainability. Anthropogenic factors that contribute to declining populations of Rafflesia are deforestation and harvesting by locals due to their perceived medicinal properties (Nais 2001; Yahya et al. 2010). The current human influence tends to be negative and leads to their extinction. This is shown by Rafflesia and its habitat which are disposed to disturbance and extinction caused by humans. Protection to avoid the extinction of Rafflesia and its habitat must be done. Basic data is needed as a reference for the efforts to preserve Rafflesia, both in terms of numbers and in terms of preserving its intact habitat.

The purpose of this study is to analyze the population structure, distribution patterns, and the effect of the physical environment of abundance R. Patma in Pananjung Pangandaran Nature Reserve, West Java. It is hoped that the data obtained from this study can be an adequate source of information so that it can be used as a policy basis for the conservation of R. Patma and its habitat in Pananjung Pangandaran Nature Reserve, West Java.

\section{MATERIALS AND METHODS}

\section{Study Area}

This research was conducted from January to April 2020 in Pananjung Pangandaran Nature Reserve, Pangandaran Regency, West Java, which is divided into 5 locations, namely Gua Parat, Badeto, Cilegon, Curug Leutik, and Pasir Putih. Pananjung Pangandaran is a peninsula on the South Coast of West Java, bordering Central Java. The location of the Pananjung Pangandaran Nature Reserve is located between $108^{\circ} 50^{\prime}$ to $109^{\circ} 55^{\prime} \mathrm{E}$ and $7^{\circ}$ $40^{\prime}$ to $7^{\circ} 45^{\prime} \mathrm{S}$. This area is bordered by the Indian Ocean to the south, Ciamis Regency to the north, Teluk Pangandaran or Pananjung in the east, and Parigi Bay to the west (Figure 1).

\section{Methods}

The method used in this study was a survey method with purposive sampling technique and sampling using quadrat plots. The sampling area was determined based on different habitat types (coastal forest including Gua Parat and Pasir Putih; lowland forest including Curug Leutik, Badeto, and Cilegon). The quadrat used is $20 \times 20 \mathrm{~m}$ in each location with five repetitions. The data collected were the number of living and dead buds, the number of flowers in live bloom, and dead flowers. Measurement of abiotic environmental factors includes temperature and humidity measured using a 


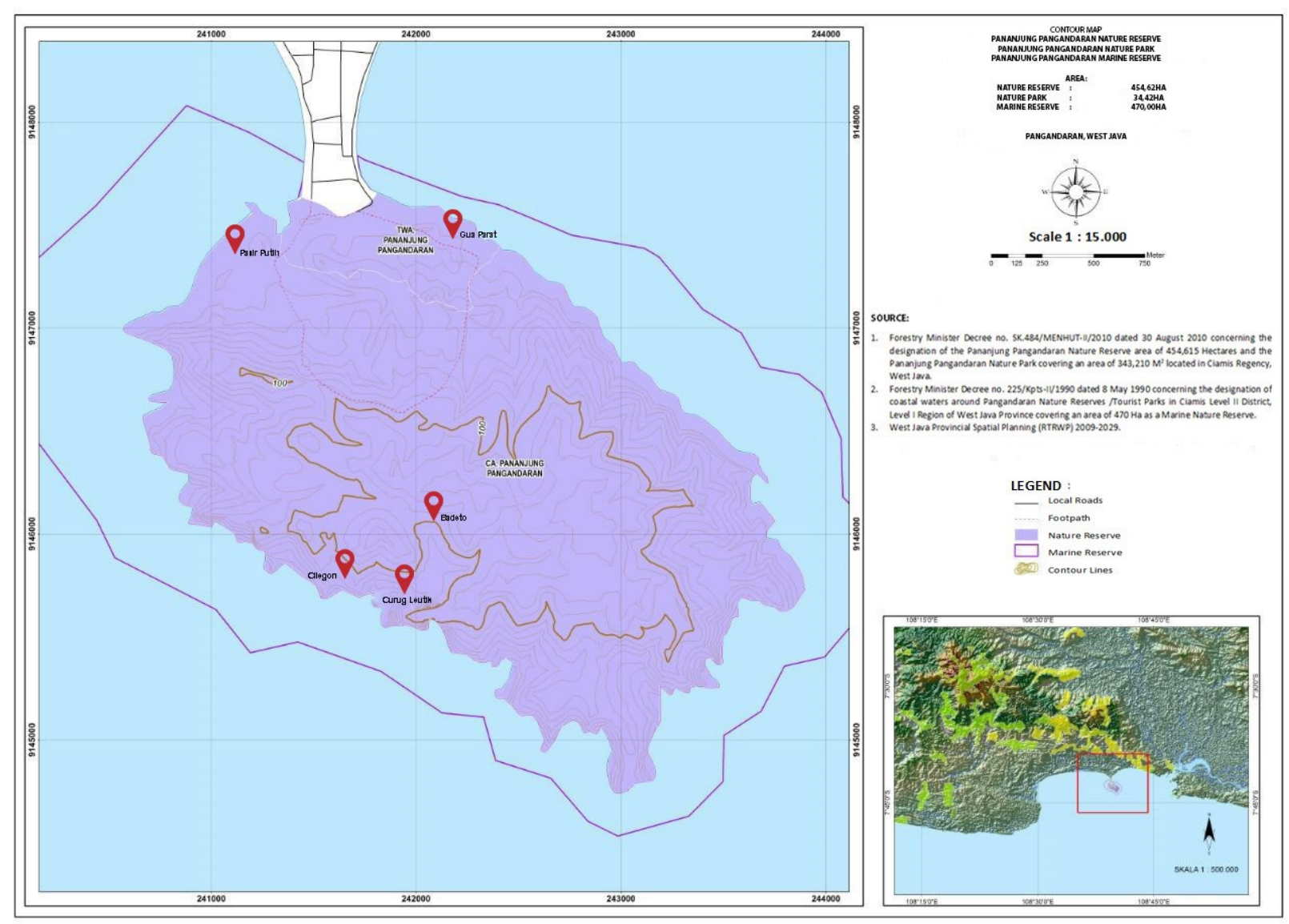

Figure 1. Map of Pananjung Pangandaran Nature Reserve, West Java, Indonesia.

thermo hygrometer, light intensity measured using a lux meter, and $\mathrm{pH}$ using a $\mathrm{pH}$ meter by measuring directly in the field on each sample plot.

Data analysis

Distribution pattern index

To find out the pattern of R. patma distribution, it can be calculated using the standardized Morisita Index (Krebs 1989). The standardized Morisita dispersion index (Ip) ranges from -1 to 1 , with $95 \%$ confidence limits at 0.5 and -0.5 .

Below was the formula used in this study:

Information:

$$
\mathrm{Id}=\mathrm{n}\left(\left(\mathrm{xi}^{2}-\Sigma \mathrm{xi}\right) /\left(\mathrm{xxi}^{2}-\Sigma \mathrm{xi}\right)\right)
$$

Id : Morisita Index

$\mathrm{n} \quad$ : Number of all plots

xi : Number of individual species on $\mathrm{i}$-th plot

Standardized of Morista index calculated by equation:

$$
\begin{array}{ll}
\text { Ip }: 0.5+0.5((\mathrm{Id}-\mathrm{Mc}) /(\mathrm{n}-\mathrm{Mc})) & \text {; if } \mathrm{Id} \geq \mathrm{Mc}>1 \\
\mathrm{Ip}: 0.5((\mathrm{Id}-1)-(\mathrm{Mc}-1)) & \text {; if } \mathrm{Mc}>\mathrm{Id} \geq 1 \\
\mathrm{Ip}: 0.5((\mathrm{Id}-1) /(\mathrm{Mu}-1)) & \text {; if } 1>\mathrm{Id}>\mathrm{Mu} \\
\mathrm{Ip}: 0.5+0.5((\mathrm{Id}-\mathrm{Mu}) /(\mathrm{Mu})) & \text {; if } 1>\mathrm{Mu}>\mathrm{Id}
\end{array}
$$

Continuously distribution pattern has been shown by $\mathrm{Mu}$ and Mc:

Information:

$$
\begin{aligned}
& \mathrm{Mu}=\left(\mathrm{x}^{2} 0.975-\mathrm{n}+\sum_{\mathrm{xi}}\right) /\left(\sum \mathrm{xi}\right)-1 \\
& \mathrm{Mc}=\left(\mathrm{x}^{2} 0.025-\mathrm{n}+\sum \mathrm{xi}\right) /\left(\sum \mathrm{xi}\right)-1
\end{aligned}
$$

$\mathrm{Mu}:$ Morista index on uniform pattern of distribution

Mc : Morista index on clustered pattern of distribution Index 
$\mathrm{x}^{2} 0.975$ : The value of $\mathrm{x}^{2}$ with $\mathrm{n}-1$ degree of freedom and confidence interval of $97.5 \%$

$\mathrm{x}^{2} 0.025$ : The value of $\mathrm{x}^{2}$ with $\mathrm{n}-1$ degree of freedom and confidence interval of $\mathrm{x}^{2} 0.025$

xi : Number of individual species on i-th plot

Principal component analysis (PCA)

The correlation between abiotic factors and the Rafflesia patma population was obtained using Principal Component Analysis (PCA) with software PAST3 (Trianto \& Purwanto 2020). PCA analysis was carried out to determine the physical factors that had the most influences based on the points of R. patma, including temperature, humidity, light intensity, and soil $\mathrm{pH}$. The PCA results will show the factor that most influences the abundance of $\mathrm{R}$. patma.

\section{RESULTS AND DISCUSSION}

\section{Population structure of Rafflesia patma}

The results of the study found that there were 114 individuals of R. patma in several research areas in Pananjung Pangandaran Nature Reserve, including Gua Parat (3 individuals), Badeto (48 individuals), Cilegon (13 individuals), Curug Leutik (38 individuals), and Pasir Putih (12 individuals) (Figure 2).

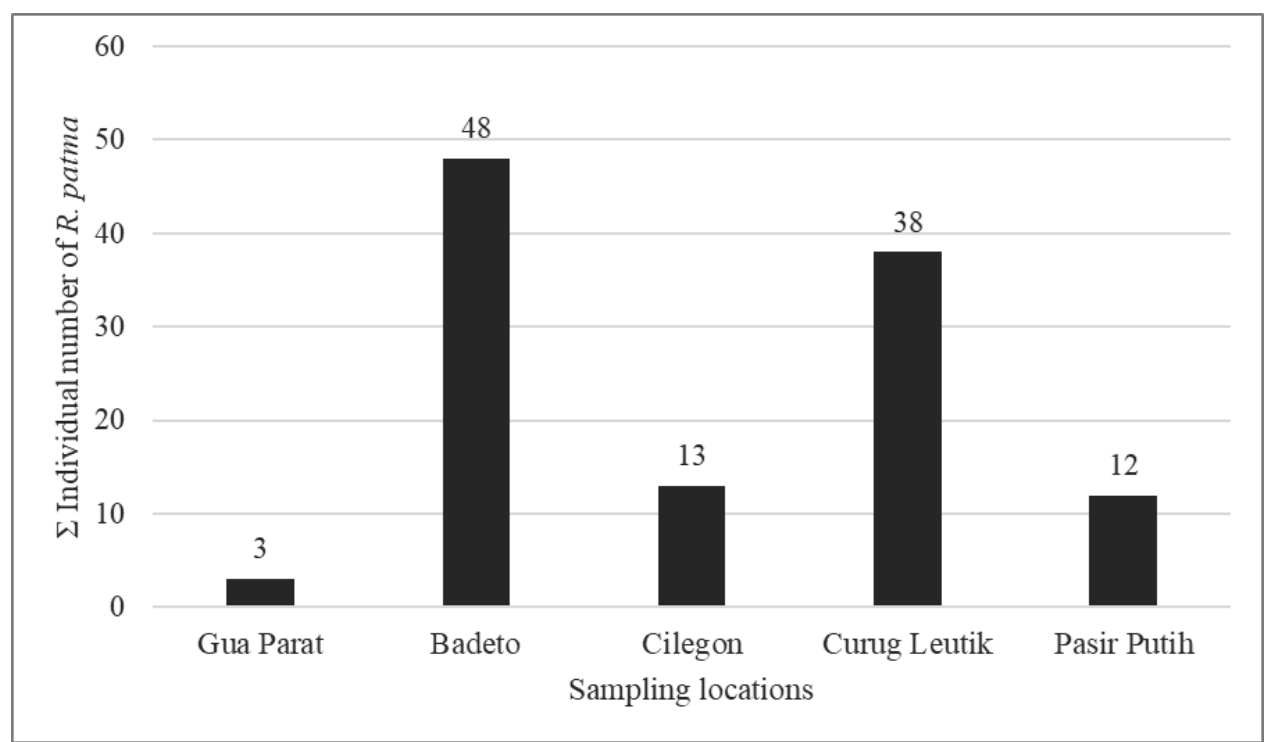

Figure 2. The number of Rafflesia patma individuals in the research area in Pananjang Pangandaran Nature Reserve.

The number of individuals found varied in each region and did not show a uniform trend in the number of individuals. This is due to the presence of different habitat conditions. The highest number of $R$. patma individuals was in the Badeto area and the lowest was in the Gua Parat area. Mursidawati \& Irawati (2017) report that Gua Parat is one of the areas that are very close to human activities. This area is around the entrance gate of the nature reserve ( $<10$ meters). The forest in this area is already fragmented by footpaths that are made to facilitate access to beaches or other tourist areas. Almost every day visitors pass through the tourist area. The population of R. patma in this area is found on the left and right of the road to the beach. Some of them grow slightly into the forest, but some of them grow right on the side of roads that are disposed of being walked on and trampled by visitors. Compared to the Badeto area (80-130 $\mathrm{m}$ asl) with the highest individual of R. patma, this area is one of the areas with a good condition, although it is often passed by visitors. The frequency of visitor arrivals in the 
Badeto area is not as intensive as in Gua Parat and Pasir Putih, because the road to this area is quite far. This area is often visited by visitors, especially during the holiday season or weekends (Mursidawati \& Irawati 2017). As additional information, Badeto Forest still has a dense population of vegetation (dense) with multi-layered strata. The buds or flowers of R. patma are scattered along the river to the waterfall directly into the sea.

Based on the results, the number of R. patma individuals observed was higher than the study of Lestari \& Rianto (2017) which consisted of 47 Rafflesia individuals (67\% alive and 33\% dead) at the Rhino-Camp Sukaraja Atas Bukit Barisan Selatan National Park (TNBBS), Susatya (2011) which consisted of 59 individuals, and Suwartini et al. (2008) consist of 57 individuals. Compared to previous studies at the same research location in Pananjung Pangandaran Nature Reserve, the results obtained were less than Mukmin \& Hikmat (2009) consisting of 312 individuals of R. patma. This population decrease is due to the existence of illegal logging and hunting of wild animals in the habitat of $R$. patma which is carried out regularly. This condition resulting in the disruption of the habitat of $\mathrm{R}$. patma which leads to the destruction of its natural habitat.

The percentage mortality of $R$. patma found in this study consisted of 54 individuals or $47.37 \%$ of dead buds, 28 individuals or $24.56 \%$ of live buds, and 32 individuals or $28.07 \%$ of rotten blooms (Figure 3, 4). Compared with the research of $R$. patma in other areas that have been carried out, the mortality rate in this study was classified as moderate, especially in the percentage of mortality R. patma before the flowers bloom. The mortality rate of R. patma in the Bojonglarang Jayanti Nature Reserve is included in the low mortality category, which is only around $12.22 \%$ (Ali et al. 2015). Susatya (2011) revealed that the Rafflesia mortality rate is low if it is in the range of 20 $-37 \%$ of deaths, and high if it is in the range of $80-100 \%$ of deaths.

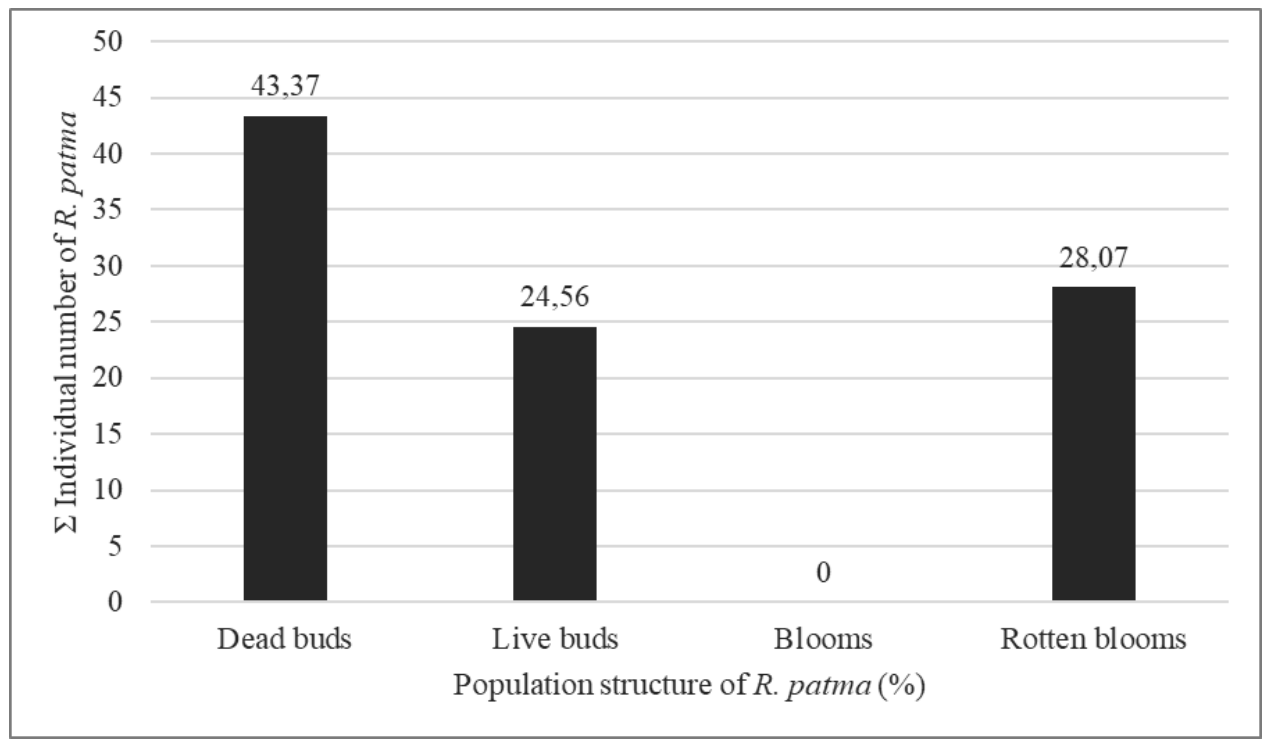

Figure 3. The population structure of Rafflesia patma in Pananjung Pangandaran Nature Reserve (Januari-April 2020).

In this study, the individual conditions of R. patma that died were different. The perigon condition of $R$. patma was black indicates that the knob has been blooming for more than one week and finally rot (Figure 4). Lestari \& Rianto (2017) suggested that the mortality that occurred in the Rafflesia flower was caused by several factors, such as the disturbance of wild animals or humans and the inadequate distribution or distribution of nutrients from the host to the Rafflesia knob. The highest mortality rate was on knobs less than $3 \mathrm{~cm}$ in diameter, whereas most knobs with a size of $>16$ 

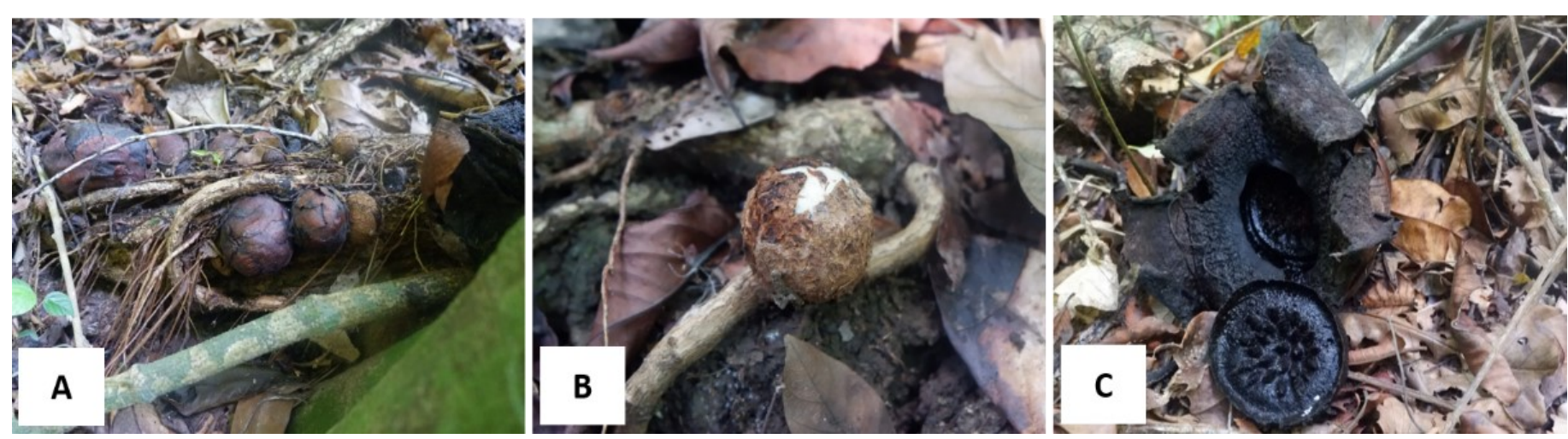

Figure 4. Condition of Rafflesia patma population: A. Dead buds, B. Live buds, and C. Rotten blooms.

cm were able to survive (Nais 2001). The mortality of Rafflesia knobs generally varied from $60 \%$ to $90 \%$ (Sofiyanti et al. 2007). Furthermore, Ramadhani et al. (2017) show that 2-3 Rafflesia knobs die before bloom. Throughout the year, R. patma is always present and is found in various phases of development, from the bud (knob) phase to fruit (Mursidawati \& Irawati 2017).

\section{Distribution pattern of Rafflesia patma}

In an ecosystem, there are three basic patterns of distribution of a species that has been recognized, namely: random, clustered, and uniform (Ludwig \& Reynolds 1988). To identify the spatial distribution pattern of a species, various distribution indices can be used, including the ratio of variance and mean, clumping index, green coefficient, standardized Morisita index. One index that is often used is the Morisita index because the results of simulation research prove that this index is the best method for measuring the spatial distribution pattern of an individual independent of population density and sample size (Morisita 1962). The standardization of the Morisita index is an improvement of the Morisita index by placing an absolute scale between -1 to 1 . The distribution pattern of organisms in a region varies widely, including organisms from members of the Rafflesiaceae family.

Members of the Rafflesiaceae family are entirely parasitic plants, including Sapria and Rhizanthes (Nikolov \& Davis 2017). This clan is popular in tropical areas, especially Southeast Asia including the Philippines and Thailand. Rafflesia can be found both in primary forests and secondary forests. Its spread is highly dependent on the spread of its host tree, namely Tetra stigma. In general, Rafflesia can be found in hosts that live near water sources. Land altitude and slope where it grows varies greatly depending on the species ranging from $5 \mathrm{~m}$ asl (R. patma in West Java) to $1400 \mathrm{~m}$ asl ( $R$. pricei in Sabah and R. rochusenii in West Java). The spread of Rafflesia in Indonesia covers the regions of Sumatra, Kalimantan, and Java (Mursidawati \& Irawati 2017), one of which is in the Pananjung Pangandaran Nature Reserve.

The population of R. patma in this study was found in five observation areas in Pananjung Pangandaran Nature Reserve, namely Gua Parat (2.63\%), Badeto (42.10\%), Cilegon (11.40\%), Curug Leutik (33.33\%), and Pasir Putih $(10.53 \%)$. Mursidawati \& Irawati (2017) suggested that the population of R. patma in Pangandaran Nature Reserve spread over several very specific areas. R. patma was found growing on hosts along the river. Some of them grow some distance from the river. In the Pasir Putih location, generally, the flowers found, both medium and past flowering, are male. The same thing was also found in Upper Badeto. The dominance of male flowers in the Pangandaran area has also been reported by Hidayati et al. (2000), that the 
Table 1. Distribution pattern of Rafflesia patma in Pananjung Pangandaran Nature Reserve.

\begin{tabular}{cccccccc}
\hline Location & $\Sigma \mathrm{xi}$ & $\mathrm{xxi}^{2}$ & $\mathrm{Id}$ & $\mathrm{Mu}$ & $\mathrm{Mc}$ & $\mathrm{Ip}$ & Distribution \\
\hline Nature reserve & 114 & 4070 & 1,535 & 0,97 & 1,06 & 0,56 & Clustered \\
\hline
\end{tabular}

Captions:

$\Sigma \mathrm{xi}=$ Total number of individual species on i-th plot

$\sum \mathrm{xi}^{2}=$ Total quadrate of number of individual species on $\mathrm{i}$-th plot

Id $\quad=$ Morisita Index

$\mathrm{Mu}=$ Morisita index on uniform pattern of distribution

Mc = Morisita index on clustered pattern of distribution

Ip $=$ Standardized of Morisita Index

area around waterfall and Rajamantri appears to have several mixed colonies between male and female.

According to the population level, the distribution pattern of R. patma in Pananjung Pangandaran Nature Reserve is clustered with the Morisita index value $>1$ (Table 1). Brower et al. (1990) explained that the distribution patterns of species in a population can be divided into three categories, namely random, uniform, and clustered. It is said to be clustered if the Morisita index value (Id) $>1$. This is in accordance with Bullock et al. (2008) statement that plant populations in nature are more often spread out in groups.

The distribution pattern of $R$. patma is related to the system and its physiological conditions in a region. Mursidawati \& Irawati (2017) and Pelser et al. (2013) explained that Rafflesia reproduces with seeds whose distribution is assisted by wind, water, and animals, including insects, hedgehogs, squirrels to wild boar, which are still estimated and need further research. This is supported by the data that the Rafflesia fruit rind is hard and tough, it can only be cracked by these animals. Physiographic conditions are also thought to be able to significantly influence the distribution of Rafflesia. This is supported by the research of Mukmin \& Hikmat (2009) that R. patma in the Pananjung Pangandaran Nature Reserve is found mostly near the Cikamal River and Tributary at the closest distance of $0.50 \mathrm{~m}$ from the water source. Other factors that also affect the distribution of R. patma are soil conditions or edaphic factors. Soil is a medium for the growth and development of plants. The soil conditions that directly affect plants are fertility. Indicators of soil fertility, among others, are seen from the content of humus or organic matter, nutrients, soil texture and structure, and the amount of water in the soil's pores ('Triana et al. 2017).

\section{Environmental conditions}

The success rate of an individual to be able to live (grow and reproduce) is influenced by physical or abiotic environmental factors. The results showed that the average temperature at the location where $\mathrm{R}$. patma was found in the Pananjung Pangandaran Nature Reserve was in the range of $28.42{ }^{\circ} \mathrm{C}$, humidity $84.52 \%$, soil $\mathrm{pH}$ equal to 5.72 , and light intensity of $1.080,5$ lux. (Table 2).

The abiotic conditions obtained in this study were included in the normal range to affect the growth of $R$. patma. Ramadhani et al. (2017) stated that the abiotic conditions of temperature $\left(25-29^{\circ} \mathrm{C}\right), 90 \%$ humidity and acidic $\mathrm{pH}$ (5.5) were able to guarantee the breeding and growth of Rafflesia in Rhino-Camp Sukaraja Atas Bukit Barisan Selatan National Park (TNBBS). Simamora et al. (2017) also reported that air humidity (76-84\%) and air temperature $\left(19.5-24.4^{\circ} \mathrm{C}\right)$ were able to support the growth of Rafflesia in Batang Gadis National Park, North Sumatra. Meanwhile, the Rafflesia species 
Table 2. Abiotic conditions of the Pananjung Pangandaran Nature Reserve.

\begin{tabular}{lcccc}
\hline \multirow{2}{*}{ Locations } & \multicolumn{4}{c}{ Abiotic Factors } \\
\cline { 2 - 5 } & Temperature $\left({ }^{\circ} \mathrm{C}\right)$ & Humidity $(\%)$ & Light intensity (lux) & $\mathrm{pH}$ \\
\hline Gua Parat & 28 & 84,8 & 1.013 & 5,54 \\
Badeto & 29 & 80,6 & $1.081,6$ & 5,8 \\
Cilegon & 27,4 & 86,4 & $1.052,8$ & 5,58 \\
Curug Leutik & 28,2 & 82,4 & $1.120,6$ & 5,58 \\
Pasir Putih & 29,4 & 88,4 & $1.134,6$ & 6,1 \\
Total & 142 & 422,6 & $5.402,6$ & 28,6 \\
Average & 28,4 & 84,52 & $1.080,5$ & 5,72 \\
\hline
\end{tabular}

found by Lestari et al. (2014) in Meru Betiri National Park grew in temperature conditions of $25-29^{\circ} \mathrm{C}$ with a humidity of $79-96 \%$.

Data of abiotic environmental conditions with the number of $\mathrm{R}$. patma individuals in five research areas in Pananjung Pangandaran Nature Reserve were further analyzed using the Principal Component Analysis (PCA) method with PAST3 software. The purpose of this analysis is to see the dominant character that affects the variation of the individual grouping pattern of R. patma. The correlation analysis between groups yielded the Eigenvalue and \% Variance shown in Table 3.

Table 3. Result Eigenvalue and \% Variance.

\begin{tabular}{ccc}
\hline PC & Eigenvalue & \% Variance \\
\hline 1 & 2451.77 & 99.595 \\
2 & 9.57712 & 0.38904 \\
3 & 0.398346 & 0.016181 \\
4 & 0.0028106 & 0.00011417 \\
\hline
\end{tabular}

The main component that can be used and represents the data in the analysis process Principal Component Analysis (PCA) is the value on PC1. A study by Bascos et al. (2019) revealed that the number of main components that can be used or is considered sufficiently representative, that is if the $\%$ variance produced is more than $70 \%$.

The results of the analysis showed that the abiotic environmental conditions could affect the distribution patterns and abundance of the R. patma population in an area. Grouping also occurs because of the role of each character being analyzed. According to Jolliffe (2002) principal component analysis is an analytical technique that is often used in taxonomic research because this technique can identify the role of each character in each formed group.

The results of the principal component analysis are shown in the PCA diagram (Figure 6). Based on the results of the PCA analysis, results were obtained that supported grouping based on cluster analysis. Based on the four abiotic environmental conditions analyzed, the most dominant character in influencing the distribution patterns and population structure of R. patma in Pananjung Pangandaran Nature Reserve is light intensity. This can be seen from the length of the resulted line (Figure 5), and the picture of Loading Plot of Component 1 (Figure 6) produced.

Light intensity greatly affects the level of air temperature in an area. The data found in this study; many light intensities occur due to the 


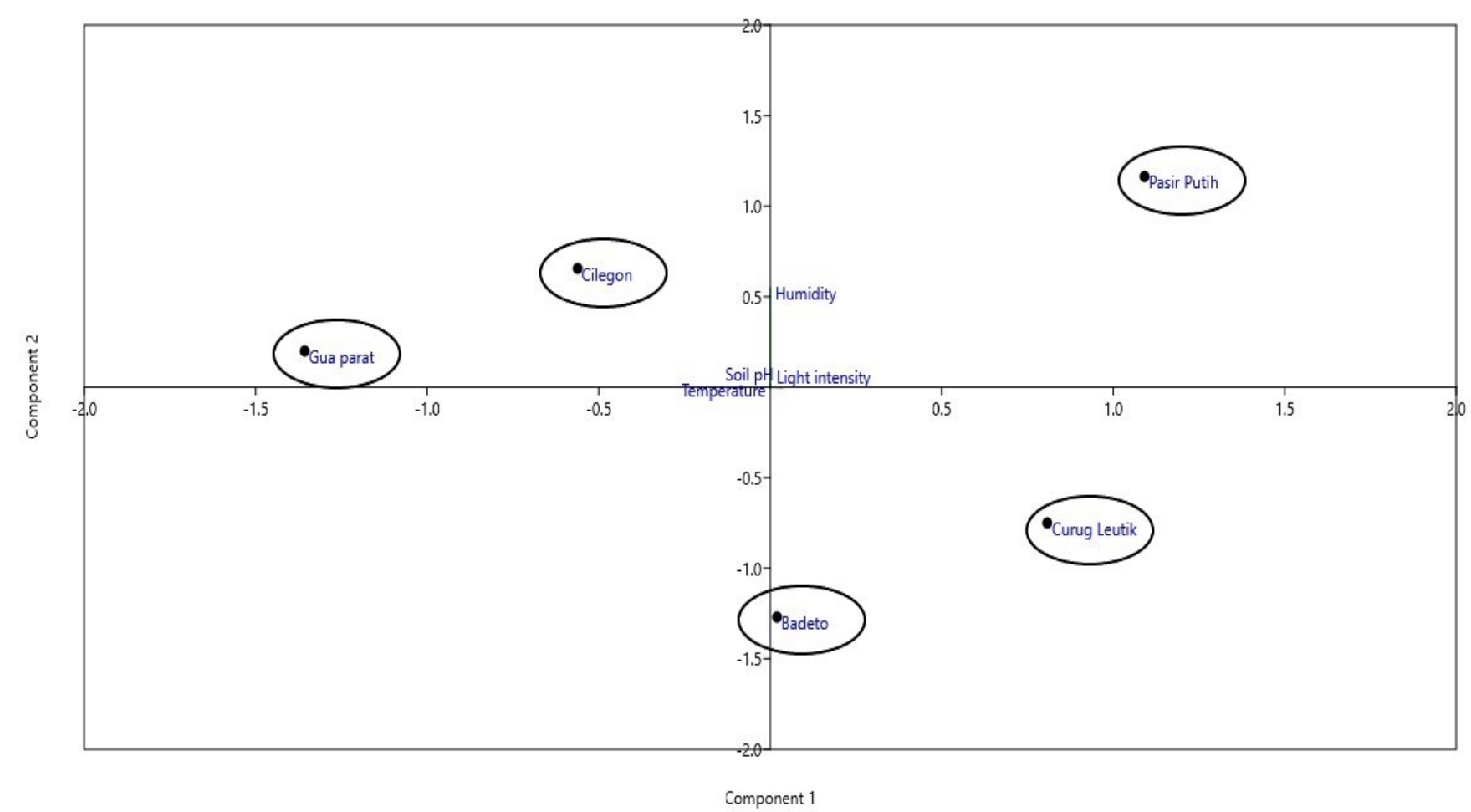

Figure 5. Biplot analysis on Principal Component Analysis (PCA) of abiotic factors that affect the abundance of Rafflesia patma.

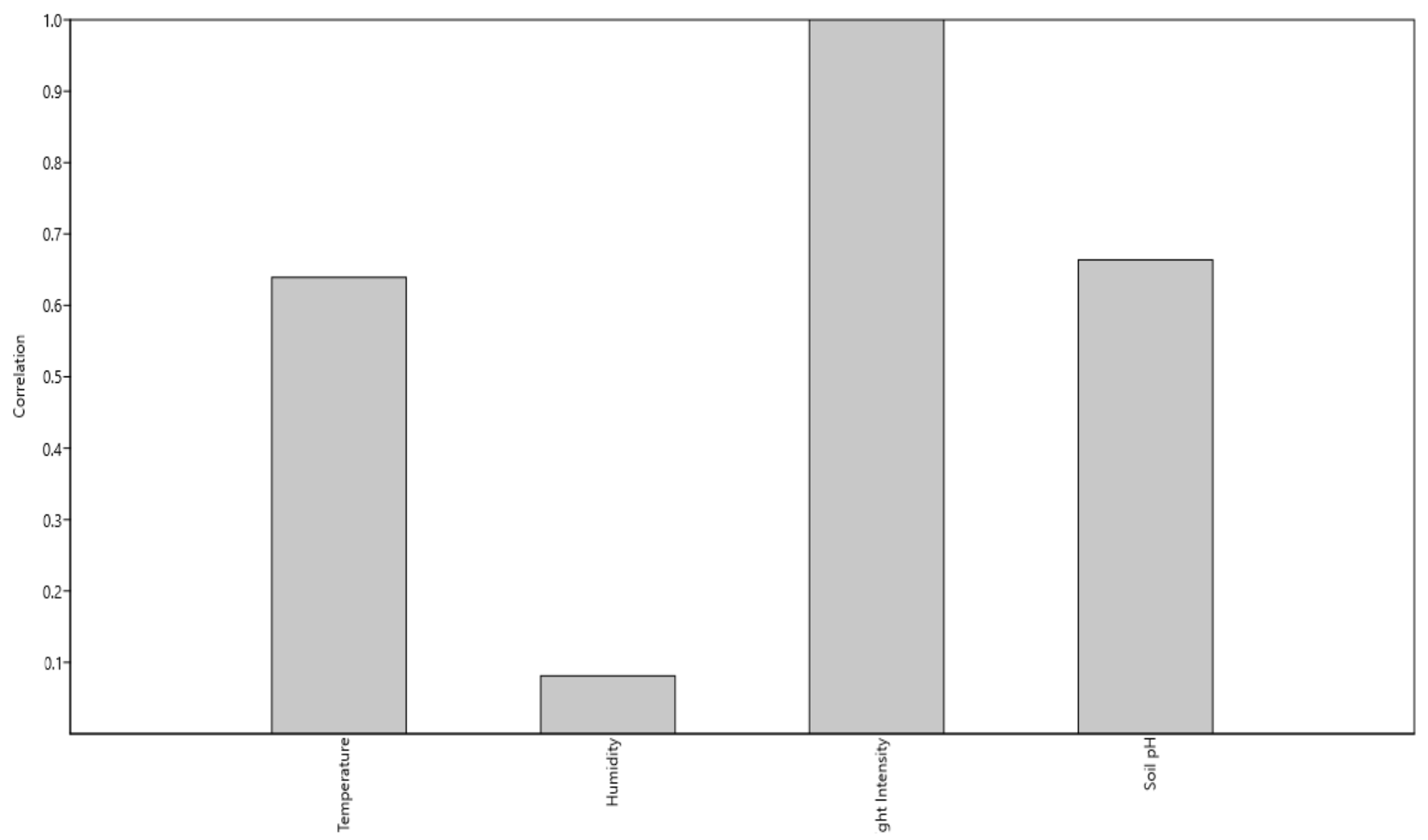

Figure 6. The Loading Plot of Component 1

openness of the forest canopy which can affect the level of sunlight reaching the forest floor. Sunlight that enters the forest floor can give a negative impact on Rafflesia survival. Exposure to the forest floor directly causes excessive evaporation and the soil surface becomes too humid so that the Rafflesia knob becomes dry and does not support Rafflesia growth (McNaughton \& Wolf 1990; Banerjee \& Linn 2018). 


\section{CONCLUSION}

There were 114 individuals of Rafflesia patma found in Pananjung

Pangandaran Nature Reserve, including 54 dead buds, 28 live buds, 32 rotten blooms, and no blooming flowers were found. The distribution pattern of R. patma in Pananjung Pangandaran Nature Reserve is clustered with the Morisita index value (Id) $>1$. The result of PCA analysis also showed that light intensity became the most affecting abiotic environmental factor on the growth of R. patma.

\section{AUTHORS CONTRIBUTION}

B.A.A. designed the research, collected and analyzed the data. B.A.A., S.H., and $\mathrm{P}$ wrote, revised, and approved the manuscript. S.H. and $\mathrm{P}$ supervised all the processes.

\section{ACKNOWLEDGMENTS}

We would like to thank the Faculty of Biology, Universitas Gadjah Mada for supporting this research. We would also thank Balai Besar Konservasi Sumber Daya Alam of West Java Region III Ciamis and Pangandaran Natural Reserve Conservation Resort for the research permit. We are also grateful to Manap Trianto, Mohamad Dahri Kisman, and Ni Luh Putu Kayika Febryanti for the help in data analysis.

\section{CONFLICT OF INTEREST}

The authors state there is no conflict of interest.

\section{REFERENCES}

Ali, M.A., Hikmat, A. \& Zuhud, E.A.M., 2015. Kajian karakteristik habitat Rafflesia (Rafflesia patma Blume) di Cagar Alam Bojonglarang Jayanti, Cianjur, Jawa Barat. Media Konservasi, 20(1), pp.9-14.

Banerjee, T. \& Linn, R., 2018. Effect of vertical canopy architecture on transpiration, Thermoregulation and carbon assimilation. Forests, 9(4), 198.

Bascos, E.M.A. et al., 2019. Philippine Rafflesia: Emerging patterns in floral morphology and distribution. Flora: Morphology, Distribution, Functional Ecology of Plants, 257, 151409.

Brower, J.E., Zar, J.H. \& Ende von, C.N., 1990, Field and Laboratory Methods for General Ecology 3rd ed., Dubuque, WCB Publishers, Lowa.

Bullock, J.M., Pywell, R.F. \& Coulson-Phillips, S.J., 2008. Managing plant population spread: Prediction and analysis using a simple model. Ecological Applications, 18(4), pp.945-953.

Hidayati, S.N. et al., 2000. A contribution to the life history of the rare Indonesian holoparasite Rafflesia patma (Rafflesiaceae). Biotropica, 32(3), pp.408-414.

Hidayati, S.N. \& Walck, J.L., 2016. A review of the Biology of Rafflesia: What do we know and what's next? Buletin Kebun Raya, 19(2), pp.67-78.

Jolliffe, I.T., 2002, Principal Component Analysis 2nd ed., Springer-Verlag New York, Inc., New York.

Krebs, C.J., 1989, Ecological Methodology, Harper and Row Publishers, New York.

Lestari, D., Hikmat, A. \& Zuhud, E.A.M., 2014. New distribution and population structure Rafflesia zollingeriana Koord. in Meru Betiri National Park, East Java. Buletin Kebun Raya, 17(2), pp.1-5.

Lestari, D. \& Rianto, N.J., 2017. Dinamika Populasi Rafflesia zollingeriana Koord di Bukit Timunan SPTN Ambulu, Taman Nasional Meru Betiri, Jawa Timur. Seminar Nasional Biodiversitas, 6(3), pp.141-144. 
Ludwig, J.A. \& Reynolds, J.F., 1988, Statistical Ecology, A Primer on Methods and Computing, John Wiley \& Sons, Inc., New York.

McNaughton, S.J. \& Wolf, L.L., 1990, Ekologi Umum, Gadjah Mada University Press, Yogyakarta.

Morisita, M., 1962. I $\sigma$-Index, a measure of dispersion of individuals. Population Ecology, 4(1), pp.1-7.

Mukmin, H. \& Hikmat, A., 2009. Kondisi Populasi Rafflesia patma Blume di Cagar Alam Pananjung Pangandaran Jawa Barat. Media Konservasi, 14(1), pp.18-21.

Mursidawati, S. \& Irawati, 2017, Biologi Konservasi Rafflesia, LIPI Press, Jakarta.

Nais, J., 2001, Rafflesia of the world, Natural History Publications, Kinabalu.

Nikolov, L.A. \& Davis, C.C., 2017. The big, the bad, and the beautiful: Biology of the world's largest flowers. Journal of Systematics and Evolution, 55(6), pp.516-524.

Pelser, P.B. et al., 2013. Mt. Banahaw reveals: The resurrection and neotypification of the name Rafflesia lagascae (Rafflesiaceae) and clues to the dispersal of Rafflesia seeds. Phytotaxa, 131(1), pp.35-40.

Priatna, D.R., Zuhud, E.A.M. \& Alikodra, H.S., 1989. Kajian Ekologis Rafflesia patma Blume Di Cagar Alam Leuweung Sancang Jawa Barat. Media Konservasi, 2(2), pp.1-7.

Ramadhani, D.N., Setiawan, A. \& Master, J., 2017. Populasi dan Kondisi Lingkungan Rafflesia arnoldii di Rhino-Camp Resort Sukaraja Atas Taman Nasional Bukit Barisan Selatan (TNBBS). Jurnal Sylva Lestari, 5 (2), pp.128-141.

Simamora, J.M., Hikmat, A. \& Zuhud, E.A.M., 2017. Pengaruh Faktor Biotik dan Fisik Lingkungan terhadap Jumlah Individu Rafflesia meijerii di Taman Nasional Batang Gadis. Media Konservasi, 22(1), pp.35-41.

Sofiyanti, N. et al., 2007. The Note on Morphology of Rafflesia hasseltii Surigar from Bukit Tiga Puluh National Park, Riau. Biodiversitas, 8(4), pp.257261.

Susatya, A., 2011, Rafflesia Pesona Bunga Terbesar di Dunia, Direktorat Kawasan Konservasi dan Bina Hutan Lindung, Departemen Kehutanan RI, Jakarta.

Suwartini, R., Hikmat, A. \& Zuhud, E.A.M., 2008. Kondisi vegetasi dan populasi Raflesia patma Blume di Cagar Alam Leuweung Sancang. Media Konservasi, 13(3), pp.1-8.

Triana, A.E., Hikmat, A. \& Basuni, S., 2017. Population of Rafflesia patma in Leuweung Cipeucang Geopark, Ciletuh, Sukabumi. Media Konservasi, 22 (2), pp.196-204.

Trianto, M. \& Purwanto, H., 2020. Morphological characteristics and morphometrics of stingless bees (Hymenoptera: Meliponini) in Yogyakarta, Indonesia. Biodiversitas, 21(6), pp.2619-2628.

Wicaksono, A. et al., 2016. Rafflesia spp.: propagation and conservation. Planta, 244(2), pp.289-296.

Yahya, A.F. et al., 2010. Distribution pattern, reproductive biology, cytotaxonomic study and conservation of Rafflesia manillana in $\mathrm{Mt}$. Makiling, Laguna, Philippines. Journal of Tropical Forest Science, 22(2), pp.118-126. 